\title{
Location and Education: Transnational Strategies among Swedish Students in New York in the Late 1990s
}

\section{Mikael Börjesson}

Uppsala University

Abstract: On the basis of a survey and a series of interviews carried out in 1998, this article attempts to sort out Swedish students' educational, professional, social, economic, and cultural gains associated with type of educational institution and geographical location of their studies. The region which was studied, the Northeastern U.S., includes a large number of very distinguished educational institutions as well as it is one of the most economically, culturally, and politically important regions in the world.

The types of institutions attended by the Swedish students follow certain logics. The most sought-after and prestigious institutions had an overrepresentation of students with large amounts of different types of capitals (cultural, educational, economic, and social), while the most dominated institutions on the American educational market, such as the least competitive universities and the community colleges, attracted students with significantly smaller resources. However; we do not see the same degree of homology between the concentration of resources in the geographical space and the different characteristics of the students. In fact, the students with fewer resources most strongly preferred the most important and powerful region, the New York Metropolitan Area.

Thus it seems that the more resourceful students invested in relatively safe options, that is, the most prestigious seats of learning, while students from more modest backgrounds and with less successful educational careers were referred to more uncertain alternatives, either in the form of studies at institutions with less prestige, where the value of the diplomas are limited, or at places where the competition is severe.

Keywords: Transnational strategies-internationalization-cultural capital- educational capital-higher education-students-the U.S.-New York-Sweden-the $1990 \mathrm{~s}$ 
The U.S. holds the most dominant position on the global educational market. ${ }^{1}$ No other country has as many foreign students. American universities are constantly at the top of international university rankings, and the American model of higher education is spread all over the world. The American influence is also clearly visible in Sweden. Although the dominance in recent years is challenged by Great Britain, the U.S. had for many decades been the most popular country in which to study. When the number of Swedish students in the U.S. was at its greatest, in 1997-98, more than 6,000 Swedes were studying at the other side of the Atlantic. ${ }^{2}$

This article will focus on the 1,100 who were attending universities and colleges in New York and surrounding states in the late 1990s. To assess the significance of American higher education for these Swedish students, the group will be examined from a number of points of view. First, we will examine the social origin, the educational assets, gender, and age of the Swedish students in relation to the kinds of schools they were enrolled at in the U.S. and the types of studies they were conducting there. The second part of the article deals with the relationship between the type of institution, the geographic location, and the students' social origin. In the third and final part, we will in further detail discuss the types of gains that are associated with the studies, on the one hand, and with the location of the educational institutions, on the other.

To determine the initial and acquired capitals ${ }^{3}$ of the students and their educational strategies ${ }^{4}$ and investments, ${ }^{5}$ a postal survey was sent in the

1 The article is based upon research conducted for my doctoral thesis, see Mikael Börjesson, Transnationella utbildningsstrategier vid svenska lärosäten och bland svenska studenter i Paris och New York, Ak. avh., Disputationsupplaga, Rapporter från Forskningsgruppen för utbildnings- och kultursociologi, nr 37, SEC/ ILU, Uppsala universitet, Uppsala 2005.

2 At the same year, 51 out of 66 Swedish universities and colleges had fewer registered students. See statistics from Swedish National Agency for Higher Education, www.hsv.se.

3 Regarding Pierre Bourdieu's concept of 'capital,' see Donald Broady, Sociologi och epistemologi. Om Pierre Bourdieus författarskap och den historiska epistemologin, HLS, Stockholm, 1991 [1990], especially pp. 169-224. In short, capital is, according to Broady, defined as resources that social groups recognize as valuable. The most important capitals are economic, cultural, and social. Educational capital, which is closely related, but not equal, to cultural capital, is the type of capital that we will investigate most thoroughly in this article. Furthermore, special attention will be given to national and transnational aspects of the types of capital. I will use the words 'resources' and 'assets' as synonyms with 'capital.'

4 'Strategies' is to be understood in the sense of Bourdieu's use of the concept, that is, as intentional and especially unintentional means of producing and reproducing one's capital and position, see ibid., pp. 179-180.

5 Concerning 'investments,' which also comes from Bourdieu's conceptual toolbox, see ibid., pp. 206-209. 
spring of 1998 to all Swedes who had been granted study loans by the Swedish National Board of Student Aid for studies in the Northeastern U.S. ${ }^{6}$ In addition, a series of loosely structured interviews with 31 students was carried out.

The geographical delimitation of the study is made to capture one of the most important regions in the world. The eleven states from Washington D.C. in the south, over New York and Massachusetts, to New Hampshire in the north contain the world's political center, Washington, D.C.; its financial and cultural center, New York - one of few truly global cities ${ }^{7}$; and the knowledge-based industries centered around Highway 128 in the Boston Area, the second most important center for innovation after Silicon Valley. ${ }^{8}$ The region also holds some of the most prestigious and resource-rich educational institutions in the world, including all the eight Ivy League universities - Harvard, Yale, Princeton, Columbia, Cornell, Pennsylvania, Brown, and Dartmouth - and some other world famous universities, such as M.I.T., Johns Hopkins University, and Georgetown University. ${ }^{9}$ To this, a number of small and very prestigious liberal arts colleges (for example Amherst College and Wellesley College in Massachusetts, Swarthmore College in Pennsylvania, and Middlebury College in Vermont) can be added. ${ }^{10}$ Apart from these distinguished seats of learning, the region assembles everything from large state university systems to municipal universities, community colleges, and small, less-known private universities and colleges.

The choice of region to study opens up for the possibility to enquire into the relation between location and education - what kind of capitals are students acquiring when they study in a global city like New York, or at a world-leading institution such as Harvard University, or at Columbia University, a top-ranked university located on Upper West Side on Manhattan?

6 During the accomplishment of the survey, I occasionally came across Sivedish students who for different reasons did not obtain/take study loans. I chose to also include these students in the study.

7 On the concept of global city, see Saskia Sassen, The Global City. New York, London, Tokyo, Princeton: Princeton University Press, 1991.

8 See Manuel Castells, The Informational City. Information Technology, Economic Restructuring, and the Urban-Regional Process, Oxford: Blackwell, 1995 [1989], passim, and Manuel Castells and Peter Hall, Technopoles of the World. The Making of $21^{s t}$ Centuries Industrial Complexes, London: Routledge, 1994, pp 29-38.

9 Among the 50 highest ranked universities, according to U.S. News and World Report 1998, 23 are found in the 11 states included in the study.

10 Here the dominance of the Northeastern U.S. is even clearer. Out of the 40 highest-ranked national liberal art colleges by U.S. News and World Report, 22 are located in the researched region. 
Furthermore, what types of and amounts of capital do the students bring with them to their studies in the States? And how are the students' resources related to their choices of places and schools?

Let us first turn to some basic background data. As can be seen in table 1, among the almost 1,100 Swedish students who were studying in the Northeastern U.S. 1998, women were in majority, making up 62 per cent. The average age among all students was 25 years. These figures can be compared to the student population in Sweden, where the average age was somewhat higher, 27.5 years, and where women were less represented, constituting 54 per cent of the student body. ${ }^{11}$ Furthermore, among those 462 who responded to the survey, ${ }^{12}$ the dominance of women was even more pronounced, 69 per cent, while the average age was the same as for the whole population of Swedish students in the Northeastern U.S. Although the Swedish students in the survey were younger than students in Sweden, they were often among the older in their American classes. American college students are typically younger, around 20-22 years old, and usually also more homogeneous with regard to age- younger students are in majority. ${ }^{13}$

11 In general, women estimate the U.S., and especially New York, highly. In her study on young Sivedes in New York in the late 1980 s, Helena Wulff found that women constituted approximately two thirds. Women were most frequently there as au pairs and artists, while men were in majority among professionals in the economic field. Helena Wulff, "Young Swedes in New York: Workplace and Playground," pp. 94-105, in Rolf Lundén \& Erik Åsard (eds), Networks of Americanization. Aspects of the American Influence in Sweden, Uppsala: Acta Universitatis Upsaliensis, Studia Anglistica Upsaliensia, 1992, pp. 94-95.

12 The response rate is 43 per cent. There are a number of factors that explain the rather low response rate. First, the survey was distributed to all students who were registered as students according to the Swedish National Board of Student Aid whether they actually started their studies or not. It is probable that the costly project of studying abroad prevented some aspiring students from actually commencing their studies. Second, students in general are usually moving a lot, and there is no reason to believe this was not also the case for Swedish students abroad. Thus it is likely that some of the questionnaires never got to the students. Third, the questionnaire was long, perhaps too long, and distributed during the semesterósome students may have judged that it was too much of an effort to complete it. An analysis of the response pattern reveals that women were more likely to answer than men, that students studying at public universities and colleges responded more often than students at private institutions. Furthermore, the responses were especially low for certain types of schools, that is, private business colleges and minor art schools. One can assume that these students were the ones furthest away from the general student that the questionnaire was designed for and that this has affected the likelihood to answer the survey.

13 In 1999, 62 per cent of the students in college were between 18 and 24 years old, 21 per cent were between 25 and 34 years old, and 18 per cent were 35 years and older. See U.S. Census Bureau, Current Population Reports, PPL-148; and earlier PPL and P-20 reports, <http://www.census.gov/population/www/socdemo/ school.html>. 
Table 1. Swedish Students in the Northeastern U.S. and Three Reference Groups. Comparative Figures Relating to Gender, Age, Grades, Social and National Origin.

\begin{tabular}{|c|c|c|c|c|c|}
\hline & $\begin{array}{l}\text { Northeastern } \\
\text { U.S. } 1998 \\
\text { total }\end{array}$ & $\begin{array}{l}\text { Northeastern } \\
\text { U.S. } 1998 \\
\text { respondents }\end{array}$ & $\begin{array}{l}\text { Students in } \\
\text { Swedish } \\
\text { higher } \\
\text { education } \\
1998\end{array}$ & $\begin{array}{c}\text { Leaving } \\
\text { compulsory } \\
\text { school } \\
1994\end{array}$ & $\begin{array}{c}\text { Leaving } \\
\text { senior } \\
\text { high } \\
\text { school } 1997\end{array}$ \\
\hline $\mathrm{N}$ & 1,085 & 462 & & & \\
\hline Females (per cent) & 62 & 69 & 54 & 51 & - \\
\hline Average age & 25 & 25 & $271 / 2$ & - & - \\
\hline High Social origin (per cent) & & 50 & 29 & 17 & - \\
\hline Working class origin (per cent) & & 8 & 19 & 34 & \\
\hline $\begin{array}{l}\text { Parents with at least } 3 \text { years higher } \\
\text { education (per cent) }\end{array}$ & & 45 & 35 & 19 & - \\
\hline $\begin{array}{l}\text { High grades from upper secondary } \\
\text { school grade }(4,5-5,0) \text { (per cent) }\end{array}$ & & 12 & 10 & - & 4 \\
\hline $\begin{array}{l}\text { Senior high school in } \\
\text { natural sciences }\end{array}$ & & 14 & 19 & - & 10 \\
\hline $\begin{array}{l}\text { National background (born } \\
\text { overseas) (per cent) }\end{array}$ & & 5 & 8 & 7 & - \\
\hline $\begin{array}{l}\text { National background (individual and } \\
\text { both parents born in Sweden) (per cent) }\end{array}$ & & 79 & 80 & - & - \\
\hline
\end{tabular}

Source: Statistics for Statistics Sweden; Student survey.

We can also conclude that the Swedish students in the Northeastern U.S. were a more socially selective group than the students in Sweden. Half of the Swedish students in the U.S. were of higher social origin (upper middle class/upper class), compared to three out of ten in Sweden. ${ }^{14}$ Interestingly, the scholastic merits did not match their inherited social resources. The proportion of the students with high grades from upper secondary school was only slightly higher than among students in Sweden (12 versus 10 per cent respectively), and a smaller percentage of the Swedish students in the

14 In general, a larger proportion of the Swedish students studying abroad have a higher social origin than students in Swedish higher education. Att studera utomlands med studiemedel, CSN rapport nr 1, Sundsvall: CSN, 1995, p. 5; SCB, Utlandsstuderande. Enkätundersökning våren 1994 bland studenter utomlands $i$ universitet och högskola läsåret 1991/92, U 10 SM 9501, SCB Stockholm 1995, p. 9. 
Northeastern U.S. had graduated from the natural science program, the most prestigious study program in senior high school (14 judged against 19 per cent). In sum, the average Swedish student in the Northeastern U.S. in 1998 was a young, female student of high social origin, exhibiting only average academic accomplishments.

Regarding the geographical distribution of the students, urban regions in general and the New York Metropolitan Area in particular dominated. As can be seen in table 2, 487, or 45 per cent of the 1,085 students, were studying in the New York Metropolitan Area. Together with the Boston Area (17 per cent), the Washington Area (6 per cent), and the Philadelphia Area (5 per cent), these major urban areas accounted for 74 per cent of the students. ${ }^{15}$ It is also noteworthy that in the New York Metropolitan Area, New York City was by far the most important location for studies and living. Of the Swedish students in the New York Metropolitan Area, 79 per cent lived and 81 per cent studied in New York City, and, of the total population of Swedish students, 39 per cent studied in the city. It is clear that New York is a very attractive city to pursue academic work, an attraction that goes far beyond the city's position on the national educational market. ${ }^{16}$

As can be seen in table 3, most of the students, or 57 per cent, studied on the undergraduate level at a four-year college or university. In addition, 11 per cent were enrolled at a community college and 13 per cent at various art schools. Only 16 per cent of the students were registered at the graduate level, and among these students, almost all of them attended Master's programs. It should also be underscored that the very small number of Ph.D.students in the group, a mere six persons, probably represents a small fraction of Swedish Ph.D.-students in the region. The majority of these students finance their studies by other means than the Swedish National Board of Student Aid, such as support from the Sweden-America Foundation and the

15 Of the students who responded to the questionnaire, the metropolitan regions were less well represented, summing up to 70 per cent. The New York Metropolitan Area in particular had a lower coverage, 38 per cent.

16 In the census year 2000 , the total population of the eleven states in the Northeastern U.S. was close to 60 millions, and the 8 million in New York City accounted for 13 per cent of the total population. Regarding higher education, the eleven states had 3.1 million students in 1996, and of these 1.0 million were studying in New York State, see U.S. Department of Education, National Center for Education Statistics, State Comparisons of Education Statistics: 1969-70 to 1996-97, NCES 98018, (Thomas Snyder, Charlene Hoffman, and Claire Geddes), Washington DC, 1998, Table 43, pp. 128-129. Although no figures are given for New York City, we can assume that no more than half of the total student population studied in New York, which gives us an estimate of the proportion of New York City around 17-18 per cent. 


\section{Table 2. Swedish Students in the Northeastern U.S. and Geographical Distribution on Metropolitan Regions.}

\begin{tabular}{lrcrc}
\hline & \multicolumn{2}{c}{ All students } & \multicolumn{2}{c}{$\begin{array}{c}\text { Students who responded } \\
\text { the survey }\end{array}$} \\
\hline No Information & $\mathrm{N}$ & Per cent & $\mathrm{n}$ & Per cent \\
New York - Northern New Jersey - & 6 & 0.6 & 0 & 0.0 \\
Long Island, NY-NJ-PA & 487 & 44.9 & 178 & 38.5 \\
(School in New York City) & $(423)$ & $(39.0)$ & $(145)$ & $(31.4)$ \\
(Living in New York City) & & & $(142)$ & $(31.0)$ \\
Boston - Cambridge - Quincy, MA-NH & 188 & 17.3 & 76 & 16.5 \\
Washington - Arlington - Alexandria, & 69 & 6.4 & 40 & 8.7 \\
DC-VA-MD-WV & & & & 6.5 \\
Philadelphia - Camden - Wilmington, & 58 & 5.3 & 30 & 6.3 \\
PA-NJ-DE-MD & 69 & 6.4 & 29 & 3.7 \\
Rhode Island & 28 & 2.6 & 17 & 6.7 \\
Connecticut & 72 & 6.6 & 31 & 5.8 \\
MA/NH/VT & 54 & 5.0 & 27 & 7.4 \\
Other NY & 54 & 5.0 & 34 & 100.0 \\
Baltimore - Towson, MD/Other MD/PA & 1,085 & 100.0 & 462 & \\
\hline Total & & & & \\
\hline
\end{tabular}

American-Scandinavian Foundation (see articles by Blanck and Melldahl in this issue), other foundations and organizations, scholarships from the American universities, private bank loans, support from one's company, etc. In fact, we do not know how large the population of Swedish Ph.D.students in the U.S. is, but it is clearly not fully represented in the survey presented in this article. The sample of Swedish undergraduate students is, on the other hand, probably more complete and representative, since it is fairly easy for students to obtain Swedish study loans (which supports almost all areas of study in higher education), and since they, to some extent, can also be combined with other means of financing.

In terms of fields of studies, business (including international business studies and marketing) was the most widespread - with 33 per cent of the students engaged in such studies (see table 4). On the whole, social science subjects were very popular (53 per cent), and they were much more common among the Swedish students in the U.S. than among Swedish students 


\section{Table 3. Swedish Students in the Northeastern U.S. and Level of Studies.}

\begin{tabular}{lcc}
\hline & Frequency & Percent \\
\hline No Information & 6 & 3.9 \\
\hline Community college & 49 & 10.6 \\
Art schools & 60 & 13.0 \\
\hline Undergraduate level, year not specified & 8 & 1.7 \\
Freshmen & 55 & 11.9 \\
Sophomore & 55 & 11.9 \\
Junior & 64 & 13.9 \\
Senior & 80 & 17.3 \\
\hline Total undergraduate & 262 & 56.7 \\
\hline Master & 67 & 14.5 \\
PhD & 6 & 1.3 \\
\hline Total graduate & 73 & 15.8 \\
\hline Total & 462 & 100.0 \\
\hline
\end{tabular}

in, for example, France (43 per cent among the Swedish students in Paris $2000)^{17}$ as well as in Sweden (26 per cent among students in Sweden in 1998)..$^{18}$ On the other hand, the arts and humanities were much more popular in most European countries than in the U.S. ${ }^{19}$ It is a bit surprising that so few of the Swedish students in the Northeastern U.S. studied natural sciences (6 per cent), technology ( 4 per cent), or medicine ( 2 per cent). All these fields of study were more highly valued in Sweden. ${ }^{20}$ In comparison with the choice of studies among Swedes in American higher education during the earlier decades of the $20^{\text {th }}$ century, as described by Blanck ${ }^{21}$ and Melldahl, ${ }^{22}$ we can notice important similarities and differences. The social

17 Mikael Börjesson, op.cit., 2005, p. 105.

18 The figures on fields of studies for students in Sweden in 1998 are from Statistics Sweden.

19 This is partly due to the fact that it is not possible to obtain study loans for studying English in the U.S.

20 Among students in Sweden in 1998, 11 per cent studied natural science, 19 per cent technology, and 13 per cent medicine (also including nursing).

21 Dag Blanck, «The Impact of the American Academy in Sweden," pp. 80-93, in Rolf Lundén \& Erik Åsard (eds), Networks of Americanization. Aspects of the American Influence in Sweden, Uppsala: Acta Universitatis Upsaliensis, Studia Anglistica Upsaliensia, 1992.

22 See Andreas Melldahl's article in this issue, and Andreas Melldahl, Västerled tur och retur: Del 1: Utbildning och ekonomi. En ekonomhistorisk studie av Sverige-Amerika Stiftelsens stipendieverksamhet 1919-2006. SEC Reports, nr 43, SEC, Uppsala: Uppsala universitet, 2008. 
Table 4. Swedish Students in the Northeastern U.S. and Level of Studies.

\begin{tabular}{|c|c|c|c|c|c|c|c|}
\hline Field of Study & $\mathrm{N}$ & $\begin{array}{l}\text { Per cent } \\
\text { of total }\end{array}$ & $\begin{array}{c}\text { Males } \\
\text { per } \\
\text { cent }\end{array}$ & Field of Study & $\mathrm{N}$ & $\begin{array}{c}\text { Per } \\
\text { cent of } \\
\text { total }\end{array}$ & $\begin{array}{c}\text { Males } \\
\text { per } \\
\text { cent }\end{array}$ \\
\hline Design & 15 & 3.2 & 6.7 & Education & 13 & 2.8 & 30.8 \\
\hline Art & 30 & 6.5 & 13.3 & & & & \\
\hline Media Production & 40 & 8.7 & 27.5 & Medicine & 7 & 1.5 & 0.0 \\
\hline Humanities & 35 & 7.6 & 14.3 & Nursing & 16 & 3.5 & 6.3 \\
\hline Languages & 11 & 2.4 & 18.2 & Total & 23 & 5.0 & 4.3 \\
\hline \multirow[t]{2}{*}{ Total } & 131 & 28.4 & 17.6 & & & & \\
\hline & & & & Computer Science & 16 & 3.5 & 56.3 \\
\hline International Business Studies & s 26 & 5.6 & 61.5 & Natural Science & 12 & 2.6 & 33.3 \\
\hline Business Studies & 89 & 19.0 & 45.5 & Total & 28 & 6.1 & 46.4 \\
\hline Marketing & 39 & 8.4 & 28.2 & & & & \\
\hline Journalism/Media & 29 & 6.3 & 10.3 & Technology & 20 & 4.3 & 65.0 \\
\hline Psykology & 16 & 3.5 & 12.5 & & & & \\
\hline Political Science & 32 & 6.9 & 23.5 & Total & 462 & 100.0 & 30.5 \\
\hline Other Social Science & 17 & 3.7 & 34.4 & & & & \\
\hline Total & 248 & 53.5 & 35.2 & & & & \\
\hline
\end{tabular}

sciences, especially economics and business studies, were central from the period after World War I and onwards, while natural sciences, technology, and medicine were more important fields of study for Swedish students in the middle of the century, than they were for their compatriots in the 1990s. However, we need to keep in mind that the older data mainly concerns graduate studies, which means that the figures are not completely comparable.

An important characteristics of the 1990s students is that most of them (87 per cent) are classified as so called "free movers," that is, they had arranged their studies abroad on their own and were not studying abroad as part of an exchange program. This figure is low in comparison to most European countries. In Europe, there is a larger proportion of exchange students due to the extensive exchange programs, such as Erasmus and Socrates, which primarily are European in their scope. Two things can be concluded from this. The longstanding position of the U.S. as the leading country for Swedish students abroad would probably have been even more dominant if the European countries had not invested in extensive exchange programs 
between its member states. Studying in the U.S. also implies something different than studying in a European country. Most of the free movers in the U.S. make whole-hearted educational investments abroad, and their principal degree is often earned there, thus making it an alternative investment to a Swedish education. For Swedish students in many European countries, their studies abroad are more often either exchange studies, where the value of their studies is added to their principal Swedish education, or language studies, which are usually limited in time to half a year or a year, and normally need to be complemented with other studies in order to pay off as fruitful educational investments.

To give a more complete account of the studies in the U.S., it is necessary to analyze the type of institution of higher education that the students attended. The American educational landscape is very extensive and varied. There is a striking difference to, for example, the Swedish and the French systems. While the Swedish and particularly the French system can best be described as centralized, the American system is very decentralized and heterogeneous:

American higher education has never been forced to conform to any one uniform pattern of organization, administration, or support. In the United States, there has been neither a national ministry of government nor a state church to impose norms of university procedure and control. The vast size of the country and the heterogeneous make-up of its population have made it difficult to establish uniformity in higher learning. ${ }^{23}$

The wide variety of higher education institutions ranges from local-recruiting community colleges and for-profit-colleges, to large state university systems and world-leading elite universities. To bring some structure to this puzzling variety, the classification of higher educational institutions by The Carnegie Foundation for the Advancement of Teaching ${ }^{24}$ and the U.S. News' university ranking ${ }^{25}$ have both been used to create a taxonomy of nine cate-

23 John S. Brubacher and Willis Rudy, Higher Education in Transition. A History of American Colleges and Universities, fourth edition, New Brunswick: Transaction, 1997 [1958], p. 59. The system has also been described as multiversity system, not a university system. See Sheldon Rothblatt, The Modern University and Its Discontents. The Fate of Newman's Legacies in Britain and America, Cambridge: Cambridge University Press, 1997 , p. 74.

24 The Carnegie Foundation for the Advancement of Teaching, The Carnegie Classification of Institutions of Higher Education, Menlo Park: Carnegie Publications, 2001.

25 U.S. News and World Report, America's Best Graduate Schools 1997, 1997, and U.S. News and World Report, America's Best Colleges 1998, 1998. 
gories of higher education institutions. ${ }^{26}$ Three categories can be considered as containing mainly what we can call elite institutions (in a double sense, they attract both students with most academic merits and with most social resources): 1) national universities (including national liberal arts colleges) at the first $\operatorname{tier}^{27}$; 2) national universities (including national liberal arts colleges) at the second highest tier ${ }^{28}$; and 3) colleges of fine arts. ${ }^{29}$ As table 5 shows, these three categories attracted approximately one out of five of the Swedish students (18 per cent). The opposite end of the spectrum was made up of community colleges, art schools, business schools, and low-ranked, regional, educational institutions that were the choice of 58 per cent of the Swedish students. In fact, the most popular type of institutions among the Swedish students was the low-ranked regional colleges, where one out of four studied ( 25 per cent). If we add to this figure the low-ranked national universities, almost half of the student population (43 per cent) is accounted for. Most of these low-ranked business schools, art schools, colleges and universities, whether regional or national, are unheard of in Sweden, and they are probably fairly unknown in the U.S. as well.

It is not possible to directly compare figures for the distribution of Swedish students at different institutions of higher education (as classified here with a combination of Carnegie Classification and the ranking by U.S. News) with figures for all students at American seats of higher learning. It is, however, possible to compare according to only the Carnegie Classification, and we then find that Swedish students are overrepresented at three types of institutions - research universities, art schools, and business schools - and largely underrepresented at community colleges. ${ }^{30}$ In gen-

26 At the first step, the Carnegie classification is used to distinguish different types of institutions, for example specialized schools, such as art schools and business schools, on the one hand, and universities and colleges, on the other. Thereafter, the rankings of the national research universities, the regional universities, and the liberal arts colleges by U.S. News and World Report are used to distinguish the highest ranked from less prestigious seats of learning within the same category. The 25 highest ranked institutions are classified as institutions of the first tier, the following 25 as the second tier, and so on.

27 Apart from the Ivy League universities, this category includes universities like Georgetown Univcrsity, Johns Hopkins University, M.I.T., and Tufts University, as well as liberal art colleges like Amherst College, Franklin and Marshall College, and Wellesley College.

28 This category includes higher education institutions such as Albert Einstein College of Medicine, Boston College, Brandeis University, New York University, Pennsylvania State University, University of Rochester, Worcester Polytechnic Institute.

29 In this category five schools are included: Mannes College of Music, Parsons School of Design, Pratt Institute, Rhode Island School of Design, and School of Visual Arts.

30 Mikael Börjesson, op.cit., 2005, p. 266. 


\section{Table 5. Swedish Students in the Northeastern U.S. and Types of Schools. By Exchange Program, Gender, Grades, Natural Science Program, French, Social and National Origin.}

\begin{tabular}{|c|c|c|c|c|c|c|c|c|c|c|c|}
\hline Type of institution & $\mathrm{N}$ & $\begin{array}{l}\text { Per } \\
\text { cent }\end{array}$ & $\begin{array}{l}\text { Ex- } \\
\text { change }\end{array}$ & Men & $\begin{array}{l}\text { Upper } \\
\text { class } \\
\text { origin }\end{array}$ & $\begin{array}{c}\text { Lower } \\
\text { class } \\
\text { origin }\end{array}$ & $\begin{array}{l}\text { Non- } \\
\text { Sivedish } \\
\text { origin }\end{array}$ & $\begin{array}{l}\text { High } \\
\text { grades }\end{array}$ & $\begin{array}{l}\text { Low } \\
\text { grades }\end{array}$ & $\begin{array}{l}\text { Natural } \\
\text { science } \\
\text { program }\end{array}$ & $\begin{array}{l}\text { Speaks } \\
\text { French }\end{array}$ \\
\hline Community College & 47 & 10.2 & 0.0 & 10.6 & 23.4 & 38.3 & 17.1 & 2.1 & 25.5 & 2.1 & 21.3 \\
\hline Business Schools & 47 & 10.2 & 2.1 & 44.7 & 48.9 & 25.5 & 8.5 & 2.1 & 31.9 & 19.1 & 17.0 \\
\hline Art schools & 60 & 13.0 & 0.0 & 16.7 & 43.3 & 15.0 & 18.3 & 13.3 & 23.3 & 3.3 & 26.7 \\
\hline Colleges of Fine Arts & 13 & 2.8 & 23.1 & 30.8 & 76.9 & 7.7 & 30.8 & 23.1 & 15.4 & 15.4 & 23.1 \\
\hline Regional 3-4 tier & 115 & 24.9 & 8.7 & 25.2 & 46.1 & 21.7 & 24.4 & 13.9 & 21.7 & 10.4 & 21.7 \\
\hline Regional $1-2$ tier & 23 & 5.0 & 0.0 & 21.7 & 56.5 & 8.6 & 12.9 & 4.3 & 26.1 & 4.3 & 17.4 \\
\hline National 3-4 tier & 85 & 18.4 & 31.8 & 40.0 & 50.6 & 12.9 & 24.7 & 16.5 & 16.5 & 11.8 & 22.4 \\
\hline National 2 tier & 26 & 5.6 & 30.8 & 38.5 & 76.9 & 3.8 & 23.0 & 53.8 & 3.8 & 19.2 & 46.2 \\
\hline National 1 tier & 46 & 10.0 & 19.6 & 50.0 & 71.7 & 2.2 & 13.0 & 52.2 & 6.5 & 52.2 & 47.8 \\
\hline Total & 462 & 100.0 & 12.6 & 30.5 & 50.2 & 17.3 & 19.8 & 17.7 & 19.9 & 14.3 & 25.8 \\
\hline
\end{tabular}

eral, then, the Swedish students are targeting the most prestigious institutions and largely ignoring the less valued institutions, with the exception of schools in art and business.

From table 5 we can observe that the Swedish students' enrollment patterns follow the social logic evident in the American system. There are considerable differences between those students who attended the most sought-after schools, the highest- and the second highest-ranked national universities, and the colleges of fine arts, and those who studied at a community college. Characteristic of the elite institutions is that they recruit students with many different kinds of resources: cultural, economic, educational, and transnational. This is also true for the Swedish students. At the highest-ranked universities, 72 per cent had a high social origin, 52 per cent had high grades from upper secondary school, 52 per cent had graduated from the natural science program in upper secondary school, 48 per cent spoke French, and 50 per cent were men. Swedish students at national universities of the second tier showed similar percentages, while all other students had considerably lower rates. The least prestigious institutions, i.e. community colleges, many business schools, and the lowest-ranked regional educational institutions, mainly attracted Swedish students with much more modest resources. For example, 2 per cent only of the Swedish stu- 
dents at a community college had high grades from upper secondary school, 2 per cent only had a natural science degree from upper secondary school, and 23 per cent came from a higher social background.

With regard to gender, table 5 shows that men were found at the extremes of the educational landscape. On the one hand, men were clearly overrepresented at the most prestigious universities (of the Swedish students at these institutions, 50 per cent were men, while there were 31 per cent men in the total population of Swedish students). On the other hand, they were also overrepresented at low-ranked business schools ( 45 per cent). Women were in general found at less prestigious types of institutions in the American field of higher education, such as regional universities ( 75 and 78 per cent compared to 69 per cent female students in total) and community colleges (90 per cent). Men were also modestly overrepresented among exchange students ( 35 per cent versus 31 per cent). This partly explains the overrepresentation in the most sought-after school types, where exchange programs were most frequent. As table 3 shows, men were also overrepresented within technology ( 65 per cent), computer science (56 per cent), international business studies ( 62 per cent), and business studies ( 46 per cent). Women, on the other hand, preferred design (93 per cent), arts ( 87 per cent), humanities ( 86 per cent), journalism ( 90 per cent), psychology ( 88 per cent), medicine (100 per cent), and nursing care (94 per cent) - fields of studies that almost no Swedish male students invested in while studying in the U.S.

We will now turn our attention to the second main theme, the relationship between the type of institutions and their geographical location, and the distribution of the students in the geographical space, thereby providing an analysis of the dispersion and concentration of the educational capital in the geographic space. The most prestigious educational institutions are concentrated in certain regions, and also the Swedish students at the highestranked national universities and liberal arts colleges were overrepresented in the Boston Area (29 per cent, while only 17 per cent of all Swedish students were found in the Boston Area) and the Philadelphia Area (14 per cent, compared to 5 per cent), while they were underrepresented in the New York Metropolitan Area ( 28 per cent against 45 per cent) (see table 6). Interestingly, there was an overrepresentation in the New York Metropolitan Area of Swedish students at the second highest-ranked national universities (59 per cent) and especially at the most prestigious colleges of fine arts (87 per cent; four out of the five schools in the category were located in New 


\section{Table 6. Swedish Students in the Northeastern U.S. and Types of Schools by Geographical Region.}

\begin{tabular}{|c|c|c|c|c|c|c|c|c|c|c|c|c|}
\hline , & & 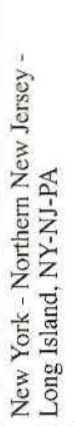 & 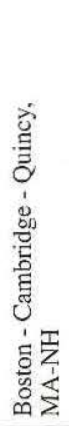 & 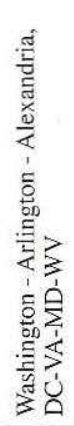 & 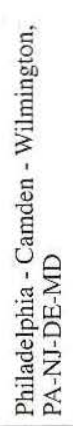 & 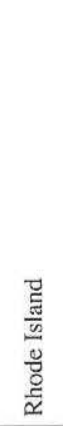 & 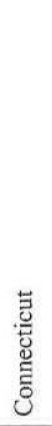 & $\sum_{\substack{\frac{1}{2} \\
\frac{1}{3}}}^{5}$ & 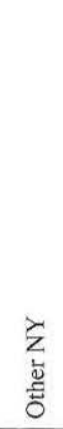 & 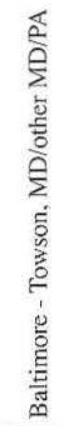 & $\frac{\alpha}{z}$ & ङ্ّ \\
\hline & $\mathrm{N}$ & 487 & 188 & 69 & 58 & 69 & 28 & 72 & 54 & 54 & 6 & 1,085 \\
\hline Community College & 80 & 25.0 & 15.0 & 15.0 & 11.3 & 0.0 & 8.8 & 0.0 & 12.5 & 12.5 & 0.0 & 100.0 \\
\hline Business Schools & 121 & 5.8 & 7.4 & 3.3 & 5.8 & 47.1 & 1.7 & 26.4 & 0.8 & 1.7 & 0.0 & 100.0 \\
\hline Art schools & 187 & 69.9 & 29.4 & 0.0 & 0.0 & 0.0 & 0.5 & 0.0 & 0.0 & 1.1 & 0.0 & 100.0 \\
\hline Colleges of Fine Arts & 40 & 87.5 & 0.0 & 0.0 & 0.0 & 12.5 & 0.0 & 0.0 & 0.0 & 0.0 & 0.0 & 100.0 \\
\hline Regional 3-4 tier & 219 & 37.9 & 24.2 & 1.8 & 4.1 & 0 . & 6.8 & 10.0 & 4.6 & 10.5 & 0.0 & 100.0 \\
\hline Regional 1-2 tier & 45 & 40.0 & 15.6 & 17.8 & 8.9 & 0.0 & 2.2 & 2.2 & 4.4 & 8.9 & 0.0 & 100.0 \\
\hline National 3-4 tier & 237 & 58.2 & 8.0 & 14.8 & 6.3 & 0.8 & 0.0 & 4.2 & 5.5 & 2.1 & 0.0 & 100.0 \\
\hline National 2 tier & 49 & 59.2 & 16.3 & 0.0 & 0.0 & 0.0 & 0.0 & 0.0 & 16.3 & 8.2 & 0.0 & 100.0 \\
\hline National 1 tier & 101 & 27.7 & 24.8 & 5.9 & 13.9 & 5.0 & 2.0 & 6.9 & 9.9 & 4.0 & 0.0 & 100.0 \\
\hline NR & 6 & 0.0 & 0.0 & 0.0 & 0.0 & 0.0 & 0.0 & 0.0 & 0.0 & 0.0 & 100.0 & 100.0 \\
\hline Total & 1,085 & 44.9 & 17.3 & 6.4 & 5.3 & 6.4 & 2.6 & 6.6 & 5.0 & 5.0 & 0.6 & 100.0 \\
\hline
\end{tabular}

York City). Less prestigious art schools are also heavily concentrated to the New York Metropolitan Area (19 out of 31 schools and almost all of these are located in New York City, more precisely on Manhattan), and 70 per cent of the Swedish students attending these schools were found in the New York Metropolitan Area. Few Swedish students studied at low-ranked business schools located in the financial center of world ( 6 per cent) ${ }^{31}$

31 The Swedish students in this category are concentrated to two schools, Johnson \& Wales University in Providence, Rhode Island (56 students), and New Hampshire College, Manchester, New Hampshire (31 students). Still, the statistics are in this respect a bit misleading, since 119 of the 219 students in the category of low-ranked national universities attended Pace University in downtown Manhattan, where almost all of them pursued business studies. 


\section{Table 7. Swedish Students in the Northeastern U.S. and Geographical Region by Social Origin.}

\begin{tabular}{|c|c|c|c|c|c|c|}
\hline & $\begin{array}{c}\text { Upper } \\
\text { Middle } \\
\text { Class- } \\
\text { Cultural } \\
\text { Fraction }\end{array}$ & $\begin{array}{l}\text { Middle } \\
\text { Class- } \\
\text { Cultural } \\
\text { Fraction }\end{array}$ & $\begin{array}{l}\text { Upper } \\
\text { Middle } \\
\text { Class- } \\
\text { Economic } \\
\text { Fraction }\end{array}$ & $\begin{array}{l}\text { Middle } \\
\text { Class- } \\
\text { Economic } \\
\text { Fraction }\end{array}$ & $\begin{array}{l}\text { Working } \\
\text { Classes }\end{array}$ & Total \\
\hline $\begin{array}{l}\text { New York - Northern New Jersey - } \\
\text { Long Island, NY-NJ-PA }\end{array}$ & 37.8 & 41.4 & 39.4 & 34.0 & 43.2 & 38.5 \\
\hline Manhattan & 41.2 & 50.0 & 57.1 & 41.7 & 37.5 & 47.8 \\
\hline Other NYC & 29.4 & 30.6 & 28.6 & 30.6 & 37.5 & 30.3 \\
\hline Other NYMA & 29.4 & 19.4 & 12.5 & 27.8 & 25.0 & 21.3 \\
\hline Boston - Cambridge - Quincy, MA-NH & 15.6 & 16.1 & 15.5 & 18.9 & 16.2 & 16.5 \\
\hline $\begin{array}{l}\text { Washington - Arlington - Alexandria, } \\
\text { DC-VA-MD-WV }\end{array}$ & 8.9 & 12.6 & 12.7 & 1.9 & 2.7 & 8.7 \\
\hline $\begin{array}{l}\text { Philadelphia - Camden - Wilmington, } \\
\text { PA-NJ-DE-MD }\end{array}$ & 7.8 & 4.6 & 4.9 & 7.5 & 10.8 & 6.5 \\
\hline Rhode Island & 2.2 & 2.3 & 11.3 & 7.5 & 2.7 & 6.3 \\
\hline Connecticut & 6.7 & 2.3 & 0.7 & 6.6 & 2.7 & 3.7 \\
\hline $\mathrm{MA} / \mathrm{NH} / \mathrm{VT}$ & 5.6 & 8.0 & 4.2 & 9.4 & 8.1 & 6.7 \\
\hline Other NY & 6.7 & 6.9 & 4.2 & 5.7 & 8.1 & 5.8 \\
\hline \multirow[t]{2}{*}{ Baltimore - Towson, MD/Other MD/PA } & 8.9 & 5.7 & 7.0 & 8.5 & 5.4 & 7.4 \\
\hline & 100.0 & 100.0 & 100.0 & 100.0 & 100.0 & 100.0 \\
\hline
\end{tabular}

While we can observe large social differences in the enrollment patterns of the most prestigious educational institutions and the less esteemed schools, the geographical regions do not show similar differences. As table 7 shows, the largest proportion of students in the New York Metropolitan Region had students of working class origin (43 per cent), an even higher proportion than among both the cultural fractions ( 38 per cent) and the economic fractions of the upper middle classes (41 per cent). ${ }^{32}$ Still, working class students living in the New York Metropolitan Area were less likely to live in Manhattan (37 per cent), than the economic fractions of the upper middle classes (57 per cent). Economic resources were thus significant.

32 Among the cultural fractions of the upper middle class, we have included university teachers, physicians, and higher civil servants, and to the economic fractions of the upper middle class private senior administrators, engineers, and private executive managers are counted. 
The distribution of the students to different types of institutions, geographical regions, and fields of studies has to be understood in relation to the different gains that are associated with them. Study abroad can offer students many different types of profit. Studies in foreign countries can be seen as an investment in educational capital, general transnational capital, more nation-specific capital, language capital, and transnational social capital. Broadly speaking, there are two ways of acquiring this capital-via the school and via the place where the studies are undertaken. Educational capital and transnational social capital are most obviously associated with schools, while the general transnational capital is more associated with place. Place can be so important that it constitutes capital in itself-a placespecific symbolic capital - as is the case with New York. Swedes studying in the U.S. emphasized this symbolic dimension in many interviews. The Swedish students usually had a thorough knowledge of New York, mostly from films, media, books, magazines, and other sources before coming to New York, and, once there, they made significant investments in acquiring a substantial knowledge of the city, its cafés, bars, restaurants, nightclubs, museums, art galleries, theaters, music venues, etc. ${ }^{33}$ Place is also the country of residence, which can function as a nation-specific transnational capital. A diploma from a low-ranked college in the Midwest is still an American diploma, with all the symbolic prestige that an American degree carries. Language capital can obviously be acquired both inside and outside a school, but is generally of different types. Official and more specialized languages dominate in the school environment, while an everyday language permeates other contexts. Transnational social capital can also be accumulated and maintained outside the school domain. New York is of course more favorable for such gains than most other places.

These returns are unevenly distributed in the educational landscape as well as in the geographical space. Elite schools are defined, among other things, by the fact that they attract students with many different types of resources. They also transfer many different kinds of capital to their students. Having studied at, for example, an Ivy League university usually means an investment in a significant educational capital, which also has global importance. These elite institutions also offer, via their alumni associations, access to an institutionalized, transnational social capital that stretches

33 Something that Helena Wulff also found in her study on young Swedes in New York. Helena Wulff, op.cit., 1992, pp. 95-96. 
across the whole world and that constitutes a large accumulation of different resources. One of the most important features of the most prestigious universities is that they constitute loci where different elites are brought together. Here, national and international meritocratic elites meet national and international social elites. Typically, these elite students bring different educational backgrounds. Some students have invested heavily in the national educational system of their native country, whether it is the U.S. or another country. Others have made an early investment in a transnational educational career through international boarding schools in Switzerland, or international schools in different parts of the world-investments that often lead to transnational careers. As one student with an international educational background put it: "The Stockholm School of Economics is a good school, but it's only a good school if you want to work in Sweden. If you're planning to work abroad, then it's a good school among many others ...," the implication being that the school he attended, The Wharton School at University of Pennsylvania, was the best choice for those who intended to pursue a global professional career. With this type of international educational background, not only does an American elite university seem more attractive, but it can also prove easier to gain entry to such universities than to elite Swedish institutions, simply because the former recruit extensively from socially exclusive international, preparatory, educational institutions, such as international boarding schools in Switzerland.

Furthermore, the value of the teaching at the elite institutions should not be underestimated. Students are often provided with opportunities to acquire competences that are very difficult to find in other places. One has access to leading scholars and professionals, very sophisticated data resources, enormous libraries and, importantly, a milieu where the majority of students are capitally strong and motivated. More often than not, it is about gaining savoir-être than savoir-faire. Students at American elite universities receive extensive training in the art of being interviewed; an experience that is very valuable for job and graduate school interviews following graduation. Another value lies in the schools' ability to place their graduates in prominent, high-status positions. Enormous resources are spent in preparing students for, and guiding them to, the most lucrative careers. But-something that must not be forgotten - the majority of the U.S. educational institutions, like those of other countries, are very different, lacking such rich resources.

In comparison to the elite schools that are relatively safe investments (students accepted at the most prestigious schools are most likely to gradu- 
ate), investments related to the place are much more uncertain. Obtaining benefits from all the opportunities and possibilities that the global city offers demands a lot of courage, patience, and especially financial means. Extremely high rents and costly living expenses come on top of tuition fees, which also can be quite high. For the most expensive schools in the U.S., the study loan does not cover even half of the costs. The educational investments are, however, not the key factor for all students for being in New York. A less prestigious and competitive institution can be accepted, as long as it gives access to one of the most fascinating and bustling cities in the world. As one student puts it:

But [being in New York City] is like it's the center of the world in a way. You cannot come any further, as far as cities go [in English] in a way. When I was growing up and lived in Malmö, I always wanted to move to Stockholm, and then you think you're done with Stockholm and see London as something. But now when I have been to New York, I realize that New York it is, and I still think it is.

For many students, being in New York means being part of a professional field with global reach. Competition is usually fierce, whether it is in jazz, haute couture, investment banking, or art. But if a student succeeds, he or she succeeds in a major way. Those who do not succeed, however, can still succeed at other places, as the place-specific symbolic value is wideranging.

Investments in the school and the place can reinforce one another, as is the case when studying at a top-ranked university in central New Yorkthere were 17 Swedish students registered at Columbia University in 1998. In the majority of cases, however, they do not (1,068 students were not registered at Columbia University). In fact, many of the most respected schools in the U.S. are situated in relatively remote regions or in the suburbs, and, in comparison to for example Paris, New York has a relatively poor selection of élite educational institutions (besides in certain areas, such as art education).

This article has attempted to sort out the students' gains associated with the educational institution and with the location of the studies. For this purpose, the region studied, the Northeastern U.S., has the benefit of containing a large number of very distinguished educational institutions as well as of being one of the most economically, culturally, and politically important regions in the world. 
First, we can conclude that to study in the Northeastern U.S. meant different things for the Swedish students found there in the late 1990s. Although there was a clear dominance of business studies in particular and social sciences in general, art and media were popular choices, especially among female students. New York was by far the most popular place to study in, but when it comes to more prestigious educational institutions, Boston and Philadelphia were more important. For art education, however, New York was almost completely dominant.

The types of institutions attended and the fields of study chosen by the Swedish students follow certain logics. The most sought-after and prestigious institutions had an overrepresentation of students with large amounts of different types of capitals, while the most dominated institutions on the American educational market, such as the least competitive schools, the community colleges, the art schools, and the business schools attracted students with significantly smaller resources. There is thus a homology between the American system of higher education and the initial resources the Swedish students bring with them. We do not see the same degree of homology between the concentration of resources in the geographical space and the students' characteristics. In fact, the students with fewer resources, typically those with working class origin, most strongly preferred the most important and powerful region, the New York Metropolitan Area.

It thus seems as if investments in highly prestigious universities and schools are less risky, compared to investments in a geographical place. If this is true, the main conclusion that can be drawn from our investigation is that the more resourceful students, the ones with extensive inherited cultural, economic, and social capital as well as acquired educational capital invested in relatively safe options, while students from more modest backgrounds and with less successful educational careers were referred to more uncertain alternatives, either in the form of studies at institutions with less prestige, where the value of the diplomas are limited, or at places where the competition is severe.

Seen in the light of the options open for Swedish students, studies in the Northeastern U.S. fulfilled different functions. For some, they were seen as a way of obtaining an education that has a value on an American and global job market, something that no Swedish university could provide to the same extent as the leading American universities. These students would probably have been accepted by Swedish institutions, but they valued these as insufficient. For others, an American education was a second chance. This 
is especially true for the most attractive areas of Swedish higher education, such as art education where competition is fierce-with usually close to one thousand applications for ten to twenty positions. Since the demand is so large for these exclusive positions, many students wanting to become artists must seek other options, and studying art in New York seems to be a very attractive alternative. For yet others, often with inferior credentials, the American system provides a different type of higher education than the ones available in Sweden: one that puts more emphasis on practical abilities than on traditional academic skills which dominate the Swedish educational system. Business schools and educational programs in marketing, business, and communication, are the best examples of such programs of study.

Still, regardless of the types of programs and institutions attended, the studies in the U.S. cannot be understood as purely educational investments. They are also investments in place-specific symbolic capital, as in the case of studies in New York; in transnational social capital, institutionalized in wide ranging alumni organizations; and, on a more general plane, in American culture. These kinds of assets are usually as important as the educational degrees the schools provide and must be taken into account if we are to understand the phenomenon labeled the internationalization of higher education. 